\title{
Gene expression profiling in hepatic tissue of newly weaned pigs fed pharmacological zinc and phytase supplemented diets
} Michelle M Martínez-Montemayor ${ }^{1,4}$, Gretchen $\mathrm{M} \mathrm{Hill}^{4}$, Nancy E Raney ${ }^{4}$, Valencia D Rilington ${ }^{4}$, Robert J Tempelman ${ }^{4}$, Jane E Link ${ }^{4}$, Christopher P Wilkinson ${ }^{2,4}$, Antonio M Ramos ${ }^{3,4}$ and Catherine W Ernst*4

Address: ${ }^{1}$ Department of Anatomy and Cell Biology, Universidad Central del Caribe, Bayamón, PR, ${ }^{2}$ McDonald Observatory, College of Natural Sciences, The University of Texas at Austin, Austin, TX, USA, ${ }^{3}$ Animal Breeding and Genomics Centre, Wageningen University, Wageningen, The Netherlands and ${ }^{4}$ Department of Animal Science, Michigan State University, East Lansing, MI, USA

Email: Michelle M Martínez-Montemayor - michelle.martinez@uccaribe.edu; Gretchen M Hill - hillgre@msu.edu; Nancy E Raney - raney@msu.edu; Valencia D Rilington - rilingto@msu.edu; Robert J Tempelman - tempelma@msu.edu; Jane E Link - linkj@msu.edu; Christopher P Wilkinson - equus@astro.as.utexas.edu; Antonio M Ramos - marcos.ramos@wur.nl; Catherine W Ernst* - ernstc@msu.edu

* Corresponding author

Published: 17 September 2008

BMC Genomics 2008, 9:42I doi:10.1|86/147|-2|64-9-42|
Received: 9 February 2008

Accepted: 17 September 2008

This article is available from: http://www.biomedcentral.com/l47|-2164/9/42I

(c) 2008 Martínez-Montemayor et al; licensee BioMed Central Ltd.

This is an Open Access article distributed under the terms of the Creative Commons Attribution License (http://creativecommons.org/licenses/by/2.0), which permits unrestricted use, distribution, and reproduction in any medium, provided the original work is properly cited.

\begin{abstract}
Background: Zinc $(\mathrm{Zn})$ is an essential trace element. However, $\mathrm{Zn}$ bioavailability from commonly consumed plants may be reduced due to phytic acid. $Z n$ supplementation has been used to treat diarrheal disease in children, and in the U.S. swine industry at pharmacological levels to promote growth and fecal consistency, but underlying mechanisms explaining these beneficial effects remain unknown. Moreover, adding supplemental phytase improves $\mathrm{Zn}$ bioavailability. Thus, we hypothesized that benefits of pharmacological $\mathrm{Zn}$ supplementation result from changes in gene expression that could be further affected by supplemental phytase. The goal of this study was to investigate the effects of feeding newly weaned pigs dietary $\mathrm{Zn} \mathrm{(I50,} \mathrm{I,000,} \mathrm{or} 2,000 \mathrm{mg} \mathrm{Zn/kg}$ ) as $\mathrm{Zn}$ oxide with or without phytase [500 phytase units (FTU)/kg] for $14 \mathrm{~d}$ on hepatic gene expression. Liver RNA from pigs fed I50, I,000, or $2,000 \mathrm{mg} \mathrm{Zn/kg}$, or I,000 mg Zn/kg with phytase ( $\mathrm{n}=4$ per treatment) was reverse transcribed and examined using the differential display reverse transcription polymerase chain reaction technique. Liver RNA from pigs fed 150 or $2,000 \mathrm{mg} \mathrm{Zn/kg} \mathrm{(}=4$ per treatment) was also evaluated using a 70 -mer oligonucleotide microarray.

Results: Expressed sequence tags for 61 putatively differentially expressed transcripts were cloned and sequenced. In addition, interrogation of a 13,297 element oligonucleotide microarray revealed 650 annotated transcripts (FDR $\leq 0.05)$ affected by pharmacological $Z n$ supplementation. Seven transcripts exhibiting differential expression in pigs fed pharmacological $\mathrm{Zn}$ with sequence similarities to genes encoding GLOI, PRDX4, ACYI, ORMI, CPB2, GSTM4, and HSP70.2 were selected for confirmation. Relative hepatic GLOI ( $P<0.0007)$, PRDX4 ( $P$ $<0.009)$ and $A C Y I(P<0.0 \mathrm{I})$ mRNA abundances were confirmed to be greater in pigs fed $\mathrm{I}, 000(\mathrm{n}=8)$ and 2,000 $(\mathrm{n}=8) \mathrm{mg} \mathrm{Zn} / \mathrm{kg}$ than in pigs fed $150(\mathrm{n}=7) \mathrm{mg} \mathrm{Zn} / \mathrm{kg}$. Relative hepatic HSP70.2 $(\mathrm{P}<0.002)$ mRNA abundance was confirmed to be lower in pigs fed $2,000 \mathrm{mg} \mathrm{Zn} / \mathrm{kg}$ than in pigs fed 150 or $1,000 \mathrm{mg} \mathrm{Zn} / \mathrm{kg}$.

Conclusion: Results suggest that feeding pharmacological $\mathrm{Zn} \mathrm{(I,000} \mathrm{or} 2,000 \mathrm{mg} \mathrm{Zn/kg})$ affects genes involved in reducing oxidative stress and in amino acid metabolism, which are essential for cell detoxification and proper cell function.
\end{abstract}




\section{Background}

Differential gene expression is responsible for morphological and phenotypical differences among animals, since the transcriptome is dynamic [1]. Studies on how micronutrients affect gene expression will help to clarify the role of trace elements in health and metabolism and their connection to biochemical events [2]. The trace mineral zinc $(\mathrm{Zn})$ is involved in gene expression in numerous ways including DNA replication, RNA transcription, through the activity of transcription factors, DNA and RNA polymerases, signal transduction, oxidative stress and playing a role in programmed cell death [3]. It was recently estimated that almost 3,000 different proteins encoded by the human genome bind zinc [4]. An example of such proteins is metallothionein (MT), which exerts a protective effect against stress by acting as an antioxidant, and as a Zn storage and transfer protein [5]. Furthermore, the transcriptional regulation of the MT gene by dietary $\mathrm{Zn}$ has been demonstrated in rats [6].

In developing countries Zn deficiency is caused by ingestion of high cereal protein diets rich in phytic acid, an organic form of phosphorus (P) [7]. In addition, common animal feedstuffs contain $60-80 \%$ of the total $\mathrm{P}$ in the phytic acid molecule, which make $\mathrm{Zn}$ unavailable for absorption [8]. Rats fed diets containing 3,000 mg Zn/kg and phytic acid absorb less and excrete more $\mathrm{Zn}$ [9]. This may be explained by the formation of mineral-phytic acid complexes, plus the negligible amount of endogenous phytase production in mammals. Therefore, the tendency to excrete phytic acid bound minerals in the feces is increased, and mineral absorption is decreased. Phytase supplementation studies in pigs demonstrate increased plasma Zn concentration $[10,11]$, greater $\mathrm{Zn}$ retention [12], and improved bone mineralization [13], while adding phytase to human diets also results in increased iron absorption [14]. Thus, phytase supplementation provides a potential solution to improve $\mathrm{Zn}$ availability.

In humans, Zn supplementation has been shown to reduce the morbidity of diarrhea [15], respiratory disease [16], and nematode infection [17]. Moreover, high Zn supplementation to weaned pigs has been successful in increasing growth and decreasing diarrhea [18], while feeding pharmacological $\mathrm{Zn}(3,000 \mathrm{mg} \mathrm{Zn} / \mathrm{kg})$ to weaned pigs improves fecal consistency and also intestinal morphology by increasing villous height and reducing crypt depths of the duodenum and jejunum [19]. However, molecular analyses of the effects of pharmacological $\mathrm{Zn}$ to explain the favorable symptoms observed when $\mathrm{Zn}$ is supplemented in high quantities have not been undertaken.

We previously reported that feeding the recommended amounts of phytase $(500 \mathrm{FTU} / \mathrm{kg}$ ) and pharmacological $\mathrm{Zn}(1,000-2,000 \mathrm{mg} / \mathrm{kg})$ to newly weaned pigs increased
MT mRNA abundance and protein concentrations in the liver, kidney and intestinal mucosa [11]. Thus, additional genes are also likely to be affected by this dietary intervention and serve as the basis for the improved health effects obtained with pharmacological $\mathrm{Zn}$ supplementation. Therefore, the objective of this experiment was to determine the identity of genes that are differentially expressed in the liver of pigs fed diets with or without pharmacological $\mathrm{Zn}$, and to determine if phytase supplementation further affected gene expression by using differential display reverse transcription polymerase chain reaction (DDRTPCR) and oligonucleotide microarray technologies. In this paper we report 61 amplicons identified by DDRTPCR and 650 annotated genes (FDR $\leq 0.05$ ) identified by microarray analysis with putative differential gene expression, of which 5 transcripts with roles in oxidative stress reduction and amino acid metabolism were confirmed to have differential expression in pigs fed pharmacological Zn diets.

\section{Results \\ Identification of expressed sequences displayed by DDRT- PCR}

A total of 66 putatively differentially expressed amplicons were cloned and sequenced. High quality nucleotide sequence data was obtained for 61 of these expressed sequence tags (ESTs) and all were submitted to the GenBank database [GenBank:CB826605 - CB826610, GenBank:CF106636 - CF106687, GenBank:DW177047 DW177050]. A search of the EMBL/GenBank and TIGR databases revealed that 29 of the ESTs (48\%) had significant similarities to genes with known identities, 7 were similar to mitochondrial DNA (11\%), and the 25 remaining sequences $(41 \%)$ had unknown identities (Table 1 ). Identified genes were similar to genes involved in signal transduction (48\%), nucleic acid metabolism (17\%), oxidative stress response $(11 \%)$, protein and amino acid metabolism $(10 \%)$, blood coagulation (7\%), and structural roles $(7 \%)$. Various mRNA abundance patterns were observed among the dietary treatment groups (Table 1) and 5 genes were selected for subsequent confirmation analyses.

\section{Identification of differentially expressed genes by oligonucleotide microarray analysis}

To further monitor gene expression changes due to pharmacological Zn supplementation, we conducted a transcriptional profiling analysis using a commercially available pig 70-mer oligonucleotide set spotted on glass slide microarrays. The hepatic transcript abundance patterns from animals fed $150 \mathrm{mg} \mathrm{Zn/kg}\left(\mathrm{Zn}_{150}\right)$ compared to animals fed 2,000 $\mathrm{mg} \mathrm{Zn} / \mathrm{kg}\left(\mathrm{Zn}_{2000}\right)$ revealed 683 annotated genes that were significantly altered at a false discovery rate (FDR) adjusted $\mathrm{P} \leq 0.05$, plus several hundred additional un-annotated oligonucleotides. Several of 
Table I: List of differentially expressed products and sequence identity information from differential display reverse transcription PCR.

\begin{tabular}{|c|c|c|c|c|}
\hline EST ID (Length - bp) & Sequence IDa & Species/Accession No.b & Porcine TC numberc & $\begin{array}{l}\text { Pattern of transcript abun- } \\
\text { dance }^{d}\end{array}$ \\
\hline
\end{tabular}

Signal Transduction Genes

$\begin{array}{cc}\text { CFI06654 (I52) } & \begin{array}{c}\text { Activator heat shock } 90 \mathrm{kDa} \text { protein ATPase } \\ \text { homologue I (AHSAI) }\end{array} \\ \text { CFI06663 (I5I) } & \begin{array}{c}\text { Activator heat shock } 90 \mathrm{kDa} \text { protein ATPase } \\ \text { homologue I (AHSAI) }\end{array} \\ \text { CFI06649 (240) } & \begin{array}{c}\text { Golgi autoantigen, golgin subfamily b, } \\ \text { macrogolgin (with transmembrane signal) I, } \\ (\text { GOLGBI) }\end{array}\end{array}$

B. taurus/NM_001034666.I

B. taurus/NM_001034666.I

H. sapiens/NM_004487.3

H. sapiens/NM_022168.2 (IFIHI)

CB826605 (152)

CB826606 (I30)

CFI06636 (484)

CFI06686 (546)

CFI06640 (240)

CFI06680 (272)

CFI06679 (354)

CFIO6667 (620)

CFI06653 (407)

DWI77048 (174)

CFI06648 (228)

CFI0665I (3I0)

CFI06652 (492)

CFI0668I (396)

CFI06666 (623)

Interferon induced with helicase $C$ domain I

$$
\begin{gathered}
\mathrm{N} \text {-myc downstream regulated gene I } \\
\text { (NDRGI) }
\end{gathered}
$$$$
\text { (NDRGI) }
$$

Orosomucoid I (ORMI)

Orosomucoid I (ORMI)

Orosomucoid I (ORMI)

component I (PGRMCI) member VII (PAQR7)

Ras, member oncogene family (RAB2A) Ribosomal protein LI7 (RPLI 7)

Ribosomal protein SA (RPSA)

Tight junction protein I (zona occludens I, $T J P I)$

Tyrosine 3-monooxygenase/Tryptophan 5monooxygenase activation protein, beta polypeptide (YWHAB)

Wilms' tumour associating protein (WTAP)

$$
\text { Basic Transcription Factor } 3 \text { (BTF3) }
$$

DNA Polymerase Beta (POLB)

Heterogeneous nuclear ribonucleoprotein $\mathrm{K}$ (HNRPK)

La ribonucleoprotein family, member 4

CFI0664I (364)

CFI06665 (479)

CFI06659 (349)

CFI06687 (278)

CFI06639 (374)

CFIO6662 (269)

$$
\text { (LARP4) }
$$

Flavin containing monooxygenase 3 (FMO3)

$$
\text { Glyoxalase I (GLOI) }
$$

Peroxiredoxin (PRDX4)

Carboxypeptidase B2 (CPB2)

Coagulation Factor IX (F9)

Histidine Rich Glycoprotein (HRG)
Progesterone receptor membrane

Progestin and adipoQ receptor family
B. taurus/NM_001035009.I

\section{S. scrofa/PIGAIAG}

S. scrofa/PIGAIAG

S. scrofa/PIGAIAG

S. scrofa/NM_2139|I.I

S. scrofa/NM_213739.I

C. familiaris/NM_001003318.1

B. taurus/NM 001034459.1

S. scrofa/AM050292.2

C. familiaris/NM_001003 I40.I

H. sapiens/NM_139323.2

H. sapiens/NM_004906.3

Nucleic Acid Metabolism Genes

H. sapiens/NM_00I207.4

B. taurus/NM 001034764.1

H. sapiens/NM_002140.2

H. sapiens/NM_199190.1

Oxidative Stress Genes

B. taurus/NM_174057.2

B. taurus/NM_001083496.1

B. taurus/NM_174433.2

\begin{tabular}{|c|c|}
\hline TC243227 & $3=4>2>1$ \\
\hline TC243227 & $3=4>2>1$ \\
\hline TC269106 & $1>2=3=4$ \\
\hline TC28I89I & $3>4>2>1$ \\
\hline TC257462 & $1>4$ \\
\hline TC273225 & I $>4$ \\
\hline TC273225 & $4>3>2=1$ \\
\hline TC273225 & $3=4>2=1$ \\
\hline TC23845I & $4=3>2>1$ \\
\hline TC238374 & $3>4>2=1$ \\
\hline TC241036 & $4=3>2>1$ \\
\hline TC26493I & $4>3>2>1$ \\
\hline TC26987I & $3>4=2>1$ \\
\hline TC28I469 & $2=3>1$ \\
\hline TC25I407 & $3=4=2>1$ \\
\hline TC267553 & $4=3>2>1$ \\
\hline TC241093 & $4=2>3>1$ \\
\hline TC252856 & $4=1>3>2$ \\
\hline TC260259 & $4=3=2>1$ \\
\hline TC2442I 8 & $3>2>1>4$ \\
\hline TC251612 & $1>2=3=4$ \\
\hline TC254694 & $4>3>2>1$ \\
\hline TC239253 & $4=3>2>1$ \\
\hline TC240093 & $3=4>2=1$ \\
\hline TC286008 & $4>2>3=1$ \\
\hline TC25II 28 & $3>4>2=1$ \\
\hline
\end{tabular}

Blood Cogulation Genes

H. sapiens/NM_001872.3

H. sapiens/NM_000I33.2

B. taurus/NM 173919.2 
Table I: List of differentially expressed products and sequence identity information from differential display reverse transcription PCR. (Continued)

\begin{tabular}{|c|c|c|c|c|}
\hline \multicolumn{5}{|c|}{ Protein and Amino Acid Metabolism Genes } \\
\hline CFI06650 (196) & N-Aminoacylase I (ACY-I) & S. scrofa/NM_213896.I & TC269425 & $4=3=2>1$ \\
\hline CFI06684 (295) & Polyubiquitin (UBB) & B. taurus/NM_I74I33.2 & TC260685 & $3=4>2=1$ \\
\hline \multicolumn{5}{|c|}{ Structural Genes } \\
\hline CFI06657 (384) & Integrin alpha-6 (ITGA6) & H. sapiens/NM_000210.2 & TC2855I5 & $1>2=3=4$ \\
\hline \multicolumn{5}{|c|}{ Mitochondrial DNA Genes } \\
\hline CFI06643 (300) & Mitochondrial DNA & S. scrofa/AB292606.I & TC259884 & $1>3>2=4$ \\
\hline CFI06645 (I77) & Mitochondrial DNA & S. scrofa/AB292606.I & TC259884 & $1>2>3=4$ \\
\hline CFI0667I (297) & Mitochondrial DNA & S. scrofa/AB292606.I & TC259884 & $4=3>2>1$ \\
\hline CFI06646 (I56) & Mitochondrial DNA & S. scrofa/AB292606.I & SINGLETON & $3>4>2=1$ \\
\hline CFI06664 (336) & Mitochondrial DNA & S. scrofa/AB292606.I & TC270954 & $1>2>3=4$ \\
\hline CFI06675 (334) & Mitochondrial DNA & S. scrofa/AB292606.I & TC270954 & $3>4=2=1$ \\
\hline CFI06647 (207) & Mitochondrial DNA & S. scrofa/AB292606.I & TC239708 & $3>4=2=1$ \\
\hline \multicolumn{5}{|c|}{ Unknown Identity Genes } \\
\hline CB826607 (I I 2)e & No significant match & & SINGLETON & I $>4$ \\
\hline CB826608 (288) $)^{\mathrm{e}}$ & No significant match & & TC292722 & I $>4$ \\
\hline CB826609 (250)e & No significant match & & SINGLETON & $1>4$ \\
\hline CB826610 (147) & No significant match & & TC26336I & I $>4$ \\
\hline CFI06637 (262) & No significant match & & TC269532 & $4=3>2>1$ \\
\hline CFI06638 (366) & No significant match & & SINGLETON & $4=2>2>1$ \\
\hline CFI06642 (557) & No significant match & & SINGLETON & $1>2=4>3$ \\
\hline CFI06644 (3I2) & No significant match & & SINGLETON & $1>2=3=4$ \\
\hline CFI06655 (2II) & No significant match & & SINGLETON & $3=4>2>1$ \\
\hline CFI06656 (222) & No significant match & & SINGLETON & $\mathrm{I}=3>2>4$ \\
\hline CFI06658 (294) & No significant match & & TC288854 & $4=2>3=1$ \\
\hline CFI06660 (209) & No significant match & & SINGLETON & $1>4=3>2$ \\
\hline CFI0666I (228) & No significant match & & SINGLETON & $1=2>3>4$ \\
\hline CFI06668 (223) & No significant match & & SINGLETON & $1>2=3=4$ \\
\hline CFI06670 (225) & No significant match & & TC2644I3 & $1=3>4>2$ \\
\hline CFI06672 (372) & No significant match & & TC275435 & $3>2>1>4$ \\
\hline CFI06674 (536) & No significant match & & SINGLETON & $3>1=2=4$ \\
\hline CFI06676 (225) & No significant match & & TC2644I3 & $3=1>4>2$ \\
\hline CFI06678 (434) & No significant match & & TC284960 & $3>4=2=1$ \\
\hline CFI06682 (317) & No significant match & & TC2642I3 & $3>4>2=1$ \\
\hline CFI06683 (364) & No significant match & & TC25670I & $3>4>2=1$ \\
\hline CFI06685 (227) & No significant match & & SINGLETON & $I=4>2<3$ \\
\hline DWI 77047 (247) & No significant match & & TC241849 & $3>1=2$ \\
\hline DWI 77049 (I58) & No significant match & & SINGLETON & $2>1=3$ \\
\hline DWI77050 (I33) & No significant match & & TC248509 & $1=2>3$ \\
\hline
\end{tabular}

aAmplicons were compared to GenBank database using the BLASTN software v. 2.2.17 August 26, 2007.

bSpecies, GenBank accession number for most significant match.

cAmplicons were compared to TIGR Sus scrofa gene index v.12.0 updated June 20, 2006 using the BLAST software v. 2.0. Singleton denotes sequences unassigned to a TC.

dPattern of transcript abundance observed on DDRT-PCR gels. I = Zn I50; $2=$ Zn I000; $3=$ Zn I000P; $4=$ Zn2000. Pattern observed in the display gel from highest (>) to lowest or comparable (=) abundance.

eAmplicons detected in Exp. I. 
these probes represent multiple spots of the same oligonucleotide. Taking this into account, a total of 650 unique genes were identified as differentially expressed at FDR $\leq$ 0.05 in the microarray analysis [see Additional file 1]. These genes have been categorized according to functional groups, and the file contains the oligonucleotide ID, fold change, raw and adjusted $\mathrm{P}$ values, and annotation for each gene.

\section{Confirmation of differential expression as affected by dietary treatment}

In the present study, we focused on genes differentially expressed due to pharmacological $\mathrm{Zn}$ supplementation, and further evaluated if their expression was affected by phytase supplementation. A total of 7 genes were selected from the display gels and microarray hybridization results that exhibited different relative mRNA abundance in the liver of pigs fed pharmacological $Z n$ diets without phytase $\left(\mathrm{Zn}_{1000}, \mathrm{Zn}_{2000}\right)$ versus pigs fed $\mathrm{Zn}_{150}$. In addition to these 7 genes, an oligonucleotide for MT on the microarray was observed to exhibit a 3.8-fold higher hepatic mRNA abundance in pigs fed $Z_{2000}$ than in pigs fed $Z_{150}$, a result which we have already confirmed in our previous study where we reported hepatic MT mRNA abundance and protein concentration to be significantly higher in pigs fed pharmacological $\mathrm{Zn}$ diets than in pigs fed an adequate $\mathrm{Zn}$ diet [11]. To confirm differential gene expression, a combination of relative real time RT-PCR and northern blot analyses were utilized with all 7 animals from Exp. 1 (fed
$\mathrm{Zn}_{150}$ or $\mathrm{Zn}_{2000}$ without phytase), and all 23 animals of Exp.2, which were fed the six dietary treatments.

Three oxidative stress response genes involved in the reduction of peroxides [peroxiredoxin 4 (PRDX4)], detoxification of glycating agents [glyoxalase I (GLO1)], and transfer of glutathione [glutathione transferase M4 (GSTM4)], exhibited differential expression. Northern blot analysis of PRDX4 revealed a single transcript of $\sim 0.95 \mathrm{~kb}$ (Figure 1), which agrees with the size reported for human PRDX4 [20]. Real time reverse transcription PCR (RT-PCR) was used to examine mRNA abundance of PRDX4. Relative abundance of PRDX4 mRNA (Figure 2A) in liver of pigs fed pharmacological $\mathrm{Zn}$ diets was 2 fold higher in pigs fed $Z \mathrm{n}_{1000}$, and 4 fold higher in pigs fed $\mathrm{Zn}_{2000}$ when compared to pigs fed $\mathrm{Zn}_{150}(P<0.009)$. This result was supported by the subsequent microarray analysis which revealed significantly higher hybridization to a PRDX4 oligonucleotide present on the array by the $\mathrm{Zn}_{2000}$ samples than by the $\mathrm{Zn}_{150}$ samples (data not shown).

PCR amplification efficiency plots revealed that GAPDH was not a suitable normalizing gene for GLO1, therefore northern blot hybridization was performed for confirmation of GLO1. A single transcript ( $1.9 \mathrm{~kb})$ was observed (Figure 1), which was in accordance with the size of human GLO1 [21]. Relative GLO1 mRNA abundance was greater $(P<0.0007)$ in pigs fed pharmacological $\mathrm{Zn}$ diets $\left(\mathrm{Zn}_{1000}\right.$ and $\left.\mathrm{Zn}_{2000}\right)$ when compared to pigs fed adequate

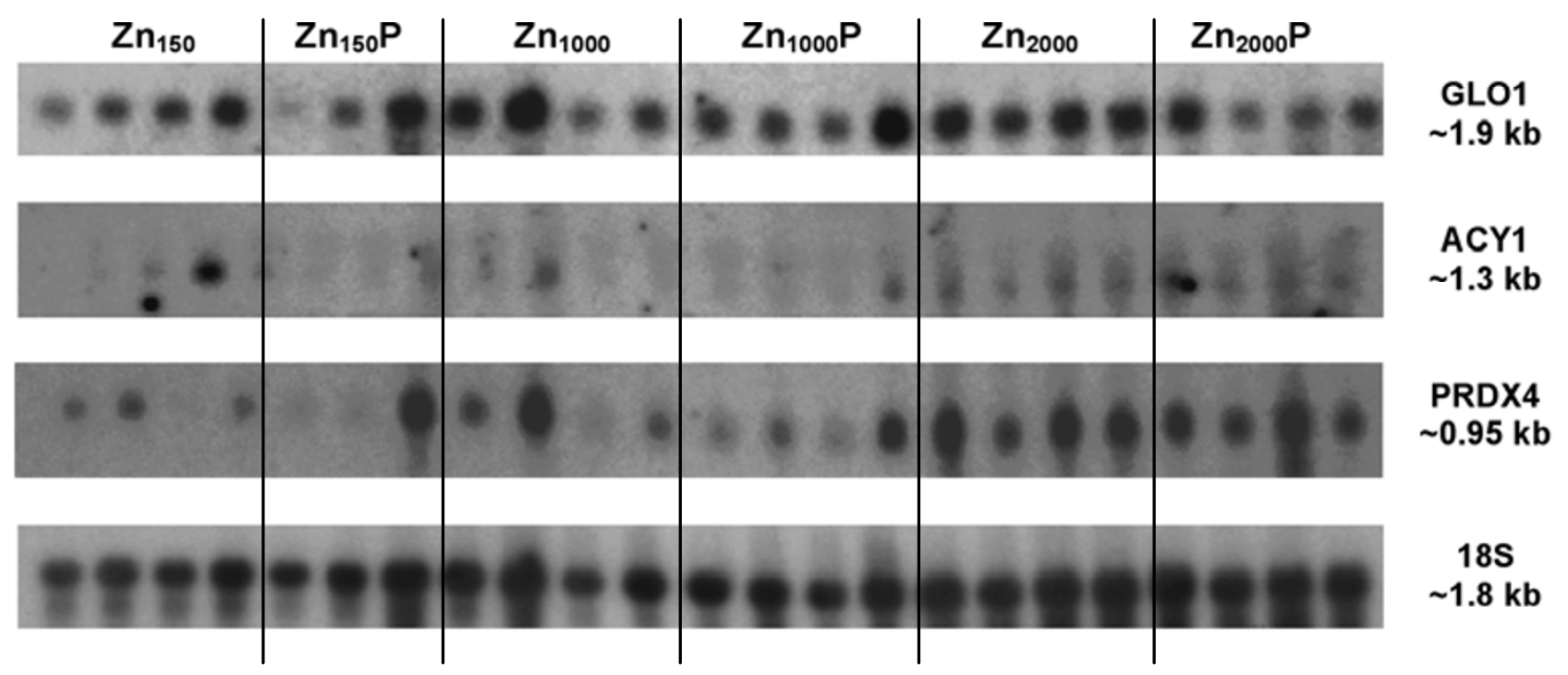

Figure I

Northern blots of GLOI, ACYI and PRDX4. Northern blot analysis of liver GLOI, ACYI and PRDX4 mRNA of pigs fed I50, I,000 or $2,000 \mathrm{mg} \mathrm{Zn/kg} \mathrm{(with} \mathrm{or} \mathrm{without} \mathrm{phytase)} \mathrm{for} \mathrm{I4} \mathrm{d} \mathrm{post-weaning} \mathrm{(Exp.2).} \mathrm{Liver} \mathrm{total} \mathrm{RNA} \mathrm{(I} 2 \mu \mathrm{g})$ isolated from each pig was analyzed using the cDNA clones derived from differential display gels as probes. Also shown is I8S rRNA hybridization to assess equivalence of RNA loading. 
A

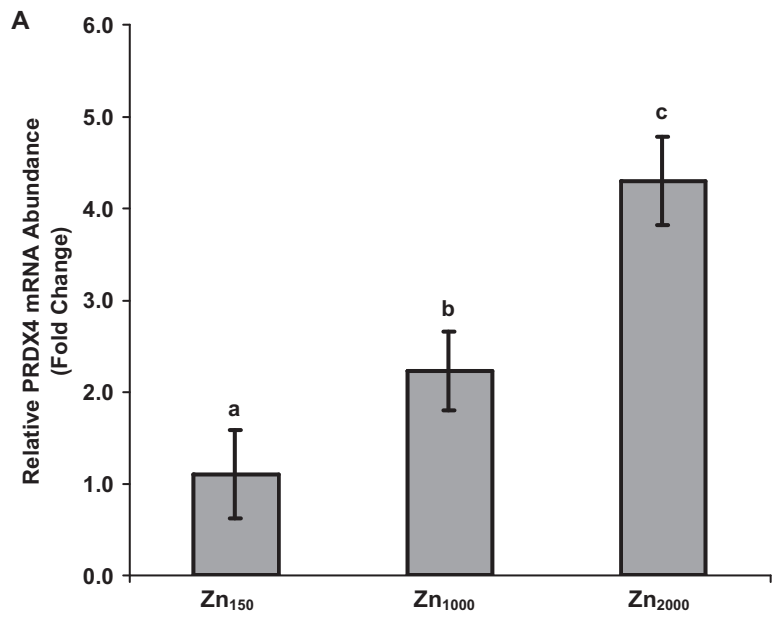

C

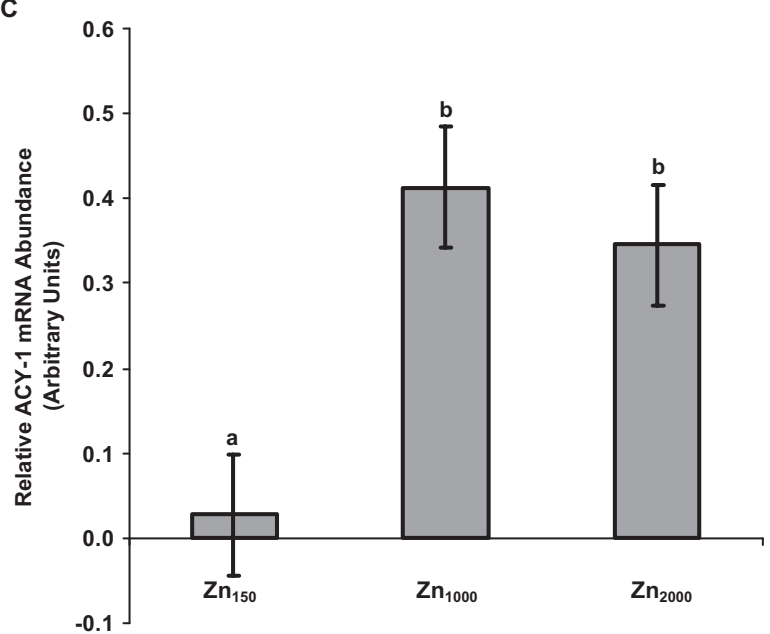

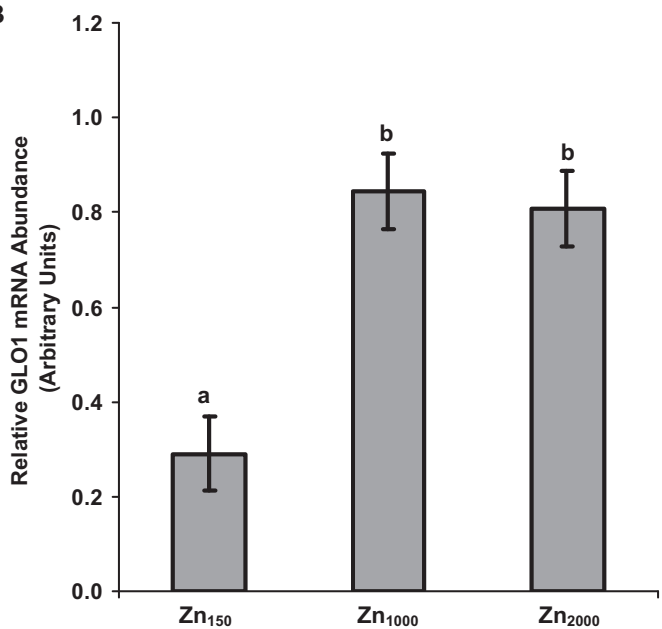

D

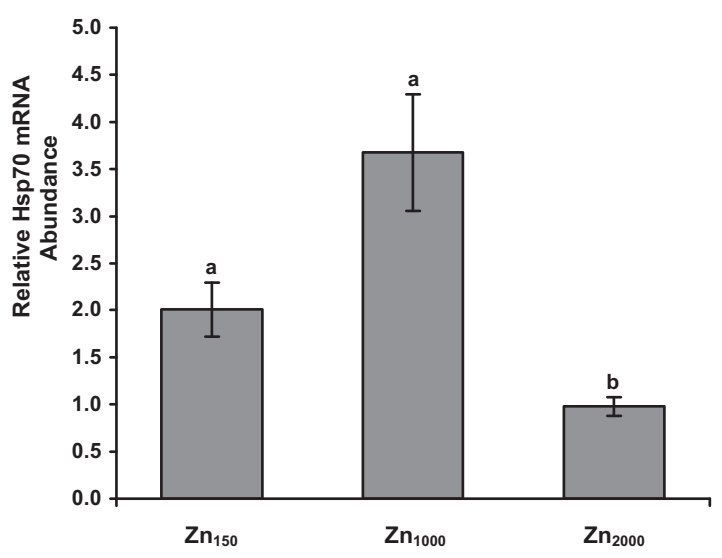

Figure 2

Gene expression confirmation of DDRT-PCR and microarray transcripts. Relative mRNA abundance of selected transcripts was confirmed using real time RT-PCR or nothern blot analyses in pigs fed 150, I,000 or 2,000 mg Zn/kg for I4 d post-weaning. A) PRDX4 mRNA Abundance. Relative real time RT-PCR was performed and fold changes relative to $G A P D H$ and a common $Z n_{150}$ reference sample are presented. Values are means $\pm S E M, n=8$, (except $Z n_{150}, n=7$ ). A significant zinc effect was detected for relative PRDX4 mRNA abundance, $P<0.009$. No $Z n$ by phytase interaction, or phytase effect were detected. B) GLOI mRNA Abundance. Northern blot analysis was performed and values are mean optical density readings $\pm S E M, n=8$ (except $Z_{150}, n=7$ ). A significant zinc effect was detected for relative hepatic $G L O I$ mRNA abundance, $P<0.0007$. No $Z n$ by phytase interaction, or phytase effect were detected. C) ACYI mRNA Abundance. Northern blot analysis was performed and values are mean optical density readings $\pm S E M, n=8\left(\right.$ except $\left.Z n_{150}, n=7\right)$. A significant zinc effect was detected for relative hepatic $A C Y I$ mRNA abundance, $P<0.01$. No $Z n$ by phytase interaction, or phytase effect were detected. D) HSP70.2 mRNA Abundance. Relative real time RT-PCR was performed and fold changes relative to $\mathrm{Zn}_{2000}$ using I8S as normalizing gene are presented. Values are means $\pm S E M, n=7$, (except $Z_{2000}, n=8$ ). A significant zinc effect was detected for relative HSP70.2 mRNA abundance, $P<0.002$. No $\mathrm{Zn}$ by phytase interaction, or phytase effect were detected. 
Zn (Figure 2B). Supplemental phytase did not affect the mRNA abundance of either PRDX4 or GLO1.

Microarray analysis had indicated GSTM4 mRNA abundance to be higher in pigs fed $Z_{2000}$ than pigs fed $Z_{150}$. Real time RT-PCR results for GSTM4 supported a trend for $\mathrm{Zn}_{2000}$ pigs to have higher GSTM4 mRNA abundance, although it did not reach statistical significance due to large animal variability. There was a trend for significance $(P<0.09)$ towards an interaction between $\mathrm{Zn}$ and phytase supplementation for relative GSTM4 mRNA abundance. GSTM4 mRNA abundance tended to increase when phytase was supplemented to the diets of pigs fed adequate $\left(\mathrm{Zn}_{150} \mathrm{P}\right)$ or the first level of pharmacological $\mathrm{Zn}$ $\left(\mathrm{Zn}_{1000} \mathrm{P}\right)$. However, when phytase was supplemented with the higher level of pharmacological $\mathrm{Zn}\left(\mathrm{Zn}_{2000} \mathrm{P}\right)$ no further increase in expression was observed.

N-aminoacylase I (ACY1) and heat shock protein 70.2 (HSP70.2) are genes involved in amino acid and heat shock metabolism that also displayed differential expression. Northern blot analysis revealed the presence of a single ACY1 transcript ( 1.3 kb, Figure 1), which is in accordance with the size reported for pig ACY1 [22]. Relative ACY1 mRNA abundance was increased $(P<0.01)$ in pigs fed pharmacological $\mathrm{Zn}\left(\mathrm{Zn}_{1000}\right.$ and $\left.\mathrm{Zn}_{2000}\right)$, and no phytase effect was observed (Figure 2C). Relative abundance of HSP70.2 mRNA in liver of pigs fed $Z_{150}$ and $\mathrm{Zn}_{1000}$ diets was comparable and higher than in pigs fed $\mathrm{Zn}_{2000}$ (Figure 2D). Supplemental phytase did not affect the mRNA abundance of HSP70.2.

Based on the differential display gels, an acute phase response gene, orosomucoid 1 (ORM1), and a gene in the plasma carboxypeptidase family, carboxypeptidase B2 (CPB2), also exhibited increased mRNA abundance in pigs fed pharmacological Zn diets. However, these genes were not confirmed to be differentially expressed in pigs fed any of the dietary treatments using relative real time RT-PCR due to large animal variability (data not shown).

\section{Discussion}

Differential display reverse transcription PCR is a technique that allows the simultaneous comparison of multiple treatments for the identification of differentially regulated mRNAs, and the generation of ESTs that can be compared with DNA sequences available in current databases to identify genes, including genes in non-conventional biological models such as the pig $[23,24]$. The disadvantage of DDRT-PCR vs. microarray approaches is clearly that it is a much more time consuming technique to perform. However, DDRT-PCR does have some advantages. Gene discovery with DDRT-PCR does not require prior knowledge of gene or EST sequences as is needed for construction of microarrays [25]. In the present study, sev- eral genes selected for confirmation from the DDRT-PCR study were not present on the microarray used for subsequent analyses despite the relatively large number of oligonucleotides on the microarray (over 13,000). In addition, DDRT-PCR allows direct comparisons to be made between more than two samples at a time and it may be more sensitive for detection of relatively low abundance transcripts. For this study, DDRT-PCR and oligonucleotide microarray technologies were used to reveal differentially expressed genes in the liver of pigs fed pharmacological $\mathrm{Zn}$ diets and to determine if expression was further affected when supplemental phytase was added to the diets. In total we found 61 ESTs with putative differential expression using DDRT-PCR among the various treatment groups and identified 650 differentially expressed $($ FDR $\leq 0.05)$ annotated genes with the microarray. Seven genes were selected for confirmation. This study provides evidence of a differential hepatic transcriptional profile in pigs due to consumption of diets containing basal or pharmacological concentrations of $\mathrm{Zn}$.

The PRDX4 gene encodes for a ubiquitous cytosolic enzyme [EC 1.11.1.15], which reduces hydrogen peroxide via redox-active cysteine residues. In addition to hydrogen peroxides, Jin and collaborators [20] reported that peroxiredoxins can also regulate peroxide-mediated signaling cascades, and their overexpression reduces hydrogen peroxides in response to tumor necrosis factor $\alpha$ (TNF- $\alpha$ ). Overexpression of PRDX4 in mice suppresses B-cell nuclear factor of kappa light polypeptide gene enhancer (Nf- $\kappa \mathrm{B}$ ) activation through regulation of B-cell inhibitor of kappa light polypeptide gene enhancer (I-кB) phosphorylation [20]. Gallagher and Phelan reported that inhibition of Nf- $\kappa \mathrm{B}$ leads to an increase in PRDXG transcription in mouse hepatocytes [26]. Similarly, MT has also been implicated in inhibiting TNF-induced activation

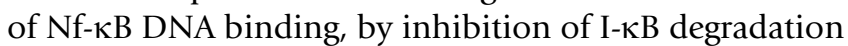
and subsequent NF-kB suppression [27]. An in vitro study demonstrated that $\mathrm{Zn}$ pretreatment increased the availability of intracellular $\mathrm{Zn}$ ions and abrogated LPS-induced oxidative stress and $\mathrm{I}-\kappa \mathrm{B} / \mathrm{NF}-\kappa \mathrm{B}$ signaling cascade in liver Kupffer cells [28]. Kim et al. [29] suggest that MT modulates intracellular signaling molecules such as transcription factors (Nf-kB) by sequestering intracellular $\mathrm{Zn}$, which is required for its DNA binding activity. Peroxiredoxins are considered redox regulators of signal transduction [20], acting like a switch to control intracellular pathways. Perhaps the increase in intracellular Zn causes an alteration in cell signaling [30], and PRDX4 upregulation occurs as a result. In addition, the suppressive effect of PRDX4 on Nf- $\mathrm{KB}$ may be one of the many mechanisms of how pharmacological $\mathrm{Zn}$, as $\mathrm{ZnO}$ enhances health in the newly weaned pig. For example, studies in Caco- 2 cells exposed to enterotoxigenic $E$. coli demonstrate that $\mathrm{Zn}$ as $\mathrm{ZnO}$ protects these cells by inhibiting bacterial adhesion 
and internalization into cells, thus modulating subsequent cytokine expression that might occur in response to pathogenic exposure [31].

Glyoxalase 1 [EC 4.4.1.5] is a cytosolic ubiquitous $\mathrm{Zn}$ metalloenzyme that catalyzes the glutathione dependent conversion of glycating agents such as methylglyoxal to SD-lactoylglutathione via a 1,2-hydrogen transfer [32]. This enzyme works in conjunction with glyoxalase II to further convert S-D-lactoylglutathione to D-lactate [33]. Methylglyoxal can react with arginine and lysine residues in proteins, and at high concentrations it inhibits glycolytic enzymes [21], enhances lipid peroxidation, and binds DNA and RNA causing macromolecular damage [34]. Genomic analysis of the GLO1 gene revealed the presence of functional metal response elements (MREs) located $647 \mathrm{bp}$ downstream of the transcription initiation site [21]. Another gene containing MREs in its promoter region is the MT gene [35]. The MREs control transcriptional activation of $M T$ upon exposure to $\mathrm{Zn}$, through the action of metal transcription factor-1 [36]. Transcriptional activity of GLO1 in transfected HepG2 cells was elevated twofold upon exposure to 25 and $75 \mu \mathrm{M} \mathrm{ZnCl}_{2}$ for $48 \mathrm{hr}$ [21]. We have previously shown that MT mRNA abundance and protein concentration are increased in liver, kidney and intestinal mucosa of pigs fed pharmacological Zn [11]. This observation was confirmed for liver MT mRNA abundance with the microarray analysis in the present study and similar expression patterns were observed for PRDX4 and GLO1.

Zinc involvement in oxidative stress is well known. Its deficiency causes oxidative DNA damage by impairment of antioxidant defense, and compromises DNA repair mechanisms [37]. However, the mechanism of how supplemental $\mathrm{Zn}$ exerts its antioxidant action is not well defined. Our current microarray analysis indicated that mRNA abundances of many oxidative stress molecules are affected by pharmacological $\mathrm{Zn}$ supplementation including GSTM4, glutathione peroxidase (GPX), NADPH oxidase (NOX1), heme oxygenase 2 (HMOX2), cytochrome C oxidase VIIB (COX7B), cytochrome P450 (CYPC27), and peroxisome proliferator activated receptor gamma-2 (PPARG) [see Additional file 1]. From these, GSTM4 was selected for confirmation. GSTM4 encodes the fourth member of the glutathione S-transferase that belongs to the mu class. The mu class of enzymes function in the detoxification of electrophilic compounds, including carcinogens, therapeutic drugs, environmental toxins and products of oxidative stress, by conjugation with glutathione [38]. Our results are in agreement with previous studies where dietary Zn affected the hepatic gene expression of GST, GPX and CYP [39]. In addition to these genes, it has been suggested that MT induction by $\mathrm{Zn}$ in hepatocytes creates an intracellular pool of thiols and $\mathrm{Zn}$ ions, thus it can act similarly to glutathione which can then react with the reactive species $[40,41]$. Moreover, the ability of $\mathrm{Zn}$ to occupy iron and copper binding sites on lipids, proteins and DNA, may also contribute towards its antioxidant action [42]. The present study shows that pharmacological $\mathrm{Zn}$ supplementation is associated with increased mRNA abundance of PRDX4 and GLO1, and a tendency to increase GSTM4 when combined with dietary phytase. Interestingly these genes participate in the oxidative stress response through differing mechanisms. Perhaps the increased intracellular concentrations of $\mathrm{Zn}$ exert an increase in Zn dependent enzymes creating an effective hepatoprotective role. Our results for hepatic GLO1 expression are in agreement with observations in GLO1 transfected HepG2 cells [21]. It is possible that $\mathrm{Zn}$ transcriptionally regulates GLO1 through MRE activation, in a similar fashion to the MT gene, therefore offering protection against glycating agents. However, to our knowledge, we provide the first evidence that dietary pharmacological $\mathrm{Zn}$ increases PRDX4 and GLO1 mRNA abundances. Additional studies will be undertaken to further clarify the influence of pharmacological Zn on GSTM4 and related oxidative stress protein activity in pigs.

Molecular chaperones or stress proteins like heat shock proteins 70.2 and 90 (Hsp70 and Hsp90), maintain the correct conformational homeostasis of proteins, helping newly synthesized proteins to be folded and transported across membranes and protecting them against a number of stresses thus playing the role of chaperones $[43,44]$. The expression of heat shock proteins is under complex control, but with final common pathways involving the heat shock factors (HSFs), the function of which is zincdependent [45]. Several heat shock proteins have been identified including Hsp27, Hsp47, Hsp70 and Hsp90, and are named according to their molecular weight [46]. In our present study we were able to confirm that pharmacological Zn decreases HSP70.2 mRNA abundance in the liver. Interestingly, in vitro studies [47] which examined the relationship between protein misfolding, aggregation and chaperone induction showed that oxidative stress increased expression of Hsp90. However, mild oxidative stress did not induce protein denaturation and stress response. This work also showed that adding $\mathrm{Zn}$ induced chaperone expression and higher $\mathrm{Zn}$ concentrations counteracted the heat shock and oxidative stress mediated induction of chaperones by inhibiting their expression [47]. These studies support our findings that at higher $\mathrm{Zn}$ concentrations, there is lower abundance of HSP70.2 mRNA.

Three additional genes were selected for confirmation. ACY1 encodes for a $\mathrm{Zn}$ metalloenzyme involved in peptide metabolism, ORM1 encodes for an acute phase reactant protein and CPB2 encodes for a plasma 
carboxypeptidase. ACY1 [EC 3.5.1.14] is a cytosolic enzyme with highest abundance in pig kidney versus the liver $[22,48]$. The biological role of ACY1 is to hydrolyze neutral and hydrophobic $\alpha-N$-acyl-L-amino acids generated during protein degradation [49]. This Zn dependent enzyme has been identified in mammals primarily in kidney and liver [48], it contains a single $\mathrm{Zn}$ atom per subunit, and it is proposed to have catalytic roles [50]. However, Heese et al. [51] suggested that $\mathrm{Zn}$ plays a structural role, because the $\mathrm{Zn}$ binding site was too far from the catalytic site of the enzyme. Results of northern blot analysis in this study confirm that pharmacological Zn supplementation increases the relative abundance of $A C Y 1$ mRNA. No differences were observed in the abundance of this transcript between animals fed $Z_{1000}$ and $Z_{2000}$, suggesting that at dietary concentrations greater than 1,000 $\mathrm{mg} \mathrm{Zn} / \mathrm{kg}$, relative $A C Y 1$ abundance reaches a plateau. To our knowledge, this study provides the first evidence of $\mathrm{Zn}$ effects on the abundance of ACY1 mRNA, suggesting a role in protein and amino acid metabolism.

Orosomucoid 1 and CPB2 are genes that encode an acute phase reactant protein known as $\alpha$-1-acid glycoprotein, and plasma pro-carboxypeptidase [EC 3.4.17.20], respectively. These plasma proteins are secreted into the blood after being synthesized in the liver $[52,53]$. Serum concentrations of ORM1 are high in fetal [54] and neonatal pigs, decreasing markedly to a constant level by $2 \mathrm{wk}$ of age [55] and declining further by $112 \mathrm{~d}$. In a similar pattern, liver ORM1 mRNA is relatively abundant in late fetal and neonatal pigs then declines rapidly after birth [56]. Alpha1 -acid glycoprotein plasma concentration rises during inflammation, thus its function is related to modulation of an inflammatory response primarily caused by interleukin 1, interleukin 6 and glucocorticoids [57]. Sequence analysis of the murine ORM1 gene revealed the presence of four MRE sequences in the $5^{\prime}$ flanking region, and one in intron 5 [58]. Furthermore, relative liver ORM1 mRNA abundance in mice injected i.p. with the heavy metal mercury $(0.5 \mathrm{mg} \mathrm{Hg} / \mathrm{kg})$ was increased in a time dependent manner. Zinc was also used to investigate ORM1 mRNA response upon heavy metal exposure, but its effect on ORM1 mRNA was not as marked as $\mathrm{Hg}$ [59]. The authors concluded that heavy metals regulate ORM1 at the transcriptional level. Interestingly, we found this gene to be affected by dietary treatment in both experiments using different anchor and arbitrary primer combinations, although the pattern of transcript abundance differed. We did not confirm a significant effect of dietary $\mathrm{Zn}$ on liver ORM1 mRNA abundance for pigs in either experiment using relative real time RT-PCR.

Plasma CPB2 [E.C. 3.4.17.20] is a carboxypeptidase that appears in plasma after clotting of blood [60]. Several names have been used for this enzyme according to its general catalytic mechanism, including carboxypeptidase $\mathrm{U}(\mathrm{U}=$ unstable), carboxypeptidase $\mathrm{R}(\mathrm{R}=$ cleaves Arg and Lys residues in C-termini), plasma carboxypeptidase B (B = basic) and most recently thrombin-activatable fibrinolysis inhibitor (TAFI) [61]. Eaton et al. [62] showed that CPB2 becomes inactive upon addition of a $\mathrm{Zn}$ chelating agent, 1,10-phenantroline. The presence of CPB2 has been demonstrated in the pig, rabbit and mouse, with activity ranging from $20 \%$ (mouse) to $500 \%$ (pig) compared to human serum CPB2 [63]. The physiological function of CPB2 is to inhibit fibrinolysis by removing Cterminal lysine residues from fibrin and limiting plasmin formation [64]. Fibrinogen is also secreted during an inflammatory response, suggesting that overexpression of CPB2 could be part of a mechanism to decrease inflammation.

Our display gels indicated that pharmacological $\mathrm{Zn}$ increases the mRNA abundance of ORM1 (for Exp. 2 pigs) and $C P B 2$ in pig liver. However, relative real time PCR results did not confirm their differential expression. The inability to confirm the differential display observations may be due to the low number of pigs examined along with relatively high variability in transcript abundance between pigs or the increased sensitivity of the real time RT-PCR assays.

\section{Conclusion}

The EST data obtained and submitted to the GenBank database as well as the transcriptional profiling from the microarray study provide sequence and differential gene expression information for hepatic genes in the pig. In addition, this study provides important information that contributes to understanding the benefits of feeding pharmacological Zn diets to pigs. New mechanisms affected by dietary $\mathrm{Zn}$ were evaluated and can be further considered in future studies, including the role of $\mathrm{Zn}$ in reducing oxidative stress and protein metabolism, both processes that are essential for cell detoxification and function.

\section{Methods \\ Animals and diets}

Animals and diet composition have been previously described [11]. A smaller preliminary study was performed to optimize the technique (Exp. 1). For Exp.1 the dietary treatments fed to pigs for $14 \mathrm{~d}$ were: 1 ) basal $\mathrm{Zn}$ diet containing $150 \mathrm{mg} \mathrm{Zn/kg}\left(\mathrm{Zn}_{150}\right)$, 2) pharmacological $\mathrm{Zn}$ diet containing $2,000 \mathrm{mg} \mathrm{Zn} / \mathrm{kg}\left(\mathrm{Zn}_{2000}\right)$. The dietary treatments fed to pigs in Exp. 2 for $14 \mathrm{~d}$ were: 1 ) adequate $\mathrm{Zn}$ diet containing $\left.150 \mathrm{mg} \mathrm{Zn} / \mathrm{kg}\left(\mathrm{Zn}_{150}\right), 2\right)$ $\mathrm{Zn}_{150}$ plus 500 phytase units (FTU)/kg $\left.\left(\mathrm{Zn}_{150} \mathrm{P}\right), 3\right)$ pharmacological $\mathrm{Zn}$ diet containing $1,000 \mathrm{mg} \mathrm{Zn} / \mathrm{kg}\left(\mathrm{Zn}_{1000}\right)$, 4) $Z_{1000}$ plus $500 \mathrm{FTU} / \mathrm{kg}\left(\mathrm{Zn}_{1000} \mathrm{P}\right)$, 5) pharmacological $\mathrm{Zn}$ diet containing $2,000 \mathrm{mg} \mathrm{Zn} / \mathrm{kg}\left(\mathrm{Zn}_{2000}\right)$, or 6) $\mathrm{Zn}_{2000}$ plus $500 \mathrm{FTU} / \mathrm{kg}\left(\mathrm{Zn}_{2000} \mathrm{P}\right)$. Pigs were provided feed and 
water ad libitum. This project was approved by the Michigan State University All University Committee on Animal Use and Care (12/99-159-00).

\section{Sample collection and total RNA isolation}

Details about euthanasia, liver sample collection and total RNA isolation were previously published [11]. Liver samples were obtained from 3 pigs per treatment for Exp. 1 (n $=6$ total) and from 4 pigs per treatment for Exp. 2 ( $\mathrm{n}=24$ total). RNA quality and integrity were determined by calculating the $\mathrm{A}_{260 / 280}$ ratio and by agarose gel electrophoresis, respectively. Additionally, RNA quality and quantity were further confirmed with the RNA 6000 Pico LabChip ${ }^{\circledR}$ kit using an Agilent 2100 Bioanalyzer (Agilent Technologies, Palo Alto, CA).

\section{Differential display reverse transcription polymerase chain reaction (DDRT-PCR)}

DDRT-PCR experiments were performed as previously reported by our laboratory [65] using modifications of published procedures [23]. Briefly, genomic DNA contamination was minimized by treating $1 \mu \mathrm{g}$ of total RNA with $1 \mathrm{U}$ of amplification grade DNAse I (Invitrogen, Life Technologies, Carlsbad, CA) according to the manufacturer's protocol. Individual DNAse treated RNA samples (200 ng) from animals fed $Z_{150}$ and $Z_{2000}(n=3$ per treatment in Exp.1) and fed $Z_{150}, Z_{1000}, Z_{1000} P$ and $\mathrm{Zn}_{2000}$ ( $\mathrm{n}=4$ per treatment in Exp. 2), were reverse transcribed by using anchor primers (Exp. 1 - Anchors \#2 and \#7, Exp. 2 - Anchor \#9) and RT-mix [1× Buffer, $25 \mu \mathrm{M}$ dNTPs, $10 \mathrm{mM}$ DTT and $40 \mathrm{U}$ of Superscript II (Invitrogen, Life Technologies, Carlsbad, CA)]. Samples were incubated at $40^{\circ} \mathrm{C}$ for $5 \mathrm{~min}, 50^{\circ} \mathrm{C}$ for $50 \mathrm{~min}$, and $70^{\circ} \mathrm{C}$ for $15 \mathrm{~min}$ in a Peltier Thermal Cycler (PTC-200, MJ Research). A final temperature drop to $4^{\circ} \mathrm{C}$ stopped the reaction.

Oligonucleotide primers for DDRT-PCR were obtained from the U.S. Pig Genome Coordination Program http:// www.animalgenome.org/pigs/resources/ddprimer.html, and those used for these experiments were randomly selected (Table 2). For Exp. 1, 2 anchor primers were paired with 2 arbitrary primers on $6 \mathrm{cDNA}$ samples and a total of 24 PCR amplicons were generated. For Exp. 2, 1 anchor primer paired with 6 arbitrary primers on 16 cDNA samples resulted in a total of 96 PCR amplicons, thus $\sim 5 \%$ of all mRNA species present were screened. PCR reactions were performed using CDNA (400 ng) in a solution containing $0.2 \mu \mathrm{M} 3$ '-anchor primer, $20 \mu \mathrm{M}$ of each dNTP, $1.5 \mathrm{mM} \mathrm{MgCl}_{2}, 1 \times$ PCR buffer, $0.2 \mu \mathrm{M} \mathrm{5} 5^{\prime}$ - arbitrary primer, $2.5 \mu \mathrm{Ci}\left[\alpha_{-}{ }^{33} \mathrm{P}\right]$ dATP (Perkin Elmer, Life Sciences Inc., Boston, MA) and 0.5 U Taq DNA Polymerase (Promega, Madison, WI). PCR cycling parameters were: $95^{\circ} \mathrm{C}$ for $2 \mathrm{~min}$, four cycles at $92^{\circ} \mathrm{C}$ for $15 \mathrm{~s}, 50^{\circ} \mathrm{C}$ for 30 $\mathrm{s}$, and $72^{\circ} \mathrm{C}$ for $2 \mathrm{~min}$, followed by an additional 25 cycles
Table 2: Anchor and arbitrary primers ${ }^{\mathrm{a}}$.

\begin{tabular}{|c|c|}
\hline Primer identification number & Primer sequence \\
\hline Anchor \# $2 \mathrm{~d}(\mathrm{~T})_{12} \mathrm{AC}$ & 5'-TTTTTTTTTTTTTGC-3' \\
\hline Anchor \# $7 \mathrm{~d}(\mathrm{~T})_{12} \mathrm{ACb}$ & 5'-TTTTTTTTTTTTCG-3' \\
\hline Anchor \# $9 \mathrm{~d}(\mathrm{~T})_{12} \mathrm{ACc}$ & 5'-TTTTTTTTTTTTAC-3' \\
\hline Arbitrary \# 4c & 5'-GCTAGCAGAC-3' \\
\hline Arbitrary \# 7c & 5'-TGGATTGGTC-3' \\
\hline Arbitrary \# 9c & 5'-TAAGCCTAGC-3' \\
\hline Arbitrary \# 13c & 5'-GTTGCACCAT-3' \\
\hline Arbitrary \# 14b & 5'-TCCATGACTC-3' \\
\hline Arbitrary \# $16^{\mathrm{d}}$ & 5'-TCGGTCATAG-3' \\
\hline Arbitrary \# $18^{\mathrm{b}}$ & 5'-TGATGCTACC-3' \\
\hline Arbitrary \# 20c & 5'-TCGATACAGG-3' \\
\hline
\end{tabular}

aSource: http://www.animalgenome.org/pigs/resources/ddprimer.html. bUsed in Exp. I.

cUsed in Exp. 2.

dUsed in Exp. I \& 2.

with annealing at $60^{\circ} \mathrm{C}$ for $30 \mathrm{~s}$ and extension at $72^{\circ} \mathrm{C}$ for 2 min.

Denaturing loading dye $(96 \%$ formamide, $2 \%$ bromophenol blue and $2 \%$ xylene cyanol) was mixed with each DDRT-PCR sample $(8 \mu \mathrm{l})$, and samples were dried on medium heat for 5 min using a speed-vacuum (Savant Instruments Inc., Farmingdale, NY) followed by a $3 \mathrm{~min} 95^{\circ} \mathrm{C}$ denaturing step. The samples were electrophoresed on $0.4 \mathrm{~mm} 5.2 \%$ polyacrylamide denaturing gels. Following a 5-6 hr run at $60 \mathrm{~W}$ on a vertical gel box (Model S2, Invitrogen, Life Technologies/GIBCO BRL Sequence Systems, Carlsbad, CA), gels were transferred onto Whatman chromatography paper (Whatman ${ }^{\circledR}$, Maidstone, England) and dried at $80^{\circ} \mathrm{C}$ for 30 min using a slab dryer (SGD 2000, Savant). Gels were exposed to Biomax $^{\text {TM }}$ film (Eastman Kodak Co., Rochester, NY) overnight.

\section{Excision and re-amplification of DDRT-PCR products}

Radiographs were developed and subsequently carefully evaluated to detect differences in transcript abundance by visually comparing bands among the different dietary treatments. Transcripts were selected that exhibited a consistent band intensity among samples within treatments and different intensities across treatments. A band intensity scale to describe the pattern of transcript abundance was created by assigning a representative number to each dietary treatment $\left(1=\mathrm{Zn}_{150} ; 2=\mathrm{Zn}_{1000} ; 3=\mathrm{Zn}_{1000} \mathrm{P} ; 4=\right.$ $\mathrm{Zn}_{2000}$ ) observed in the display gel from highest $(>)$ to lowest or comparable $(=)$ abundance (Table 1$)$. Selected bands were circumscribed from the gels, re-hydrated in $100 \mu \mathrm{l} \mathrm{DEPC}$-treated water and heated at $50^{\circ} \mathrm{C}$ for 30 min. Re-amplification reactions included $2 \mu \mathrm{l}$ of gel band eluate and the anchor and arbitrary primers used in the DDRT-PCR step under the same reaction conditions and cycling parameters described above, excluding the iso- 
tope. To assess quality of the reactions, 1 and $2 \mu \mathrm{l}$ of reamplified products were electrophoresed with a $\lambda$ Hind III marker (Invitrogen, Life Technologies, Carlsbad, CA) in $1 \%$ agarose gels stained with ethidium bromide (SigmaAldrich, St. Louis, MO).

\section{Cloning and sequencing of DDRT-PCR products}

Products of interest obtained from the DDRT-PCR gels were cloned into pGEM-T-Easy Vector-System I (Promega, Madison, WI). Recombinant vectors were transformed into E. coli DH5 $\alpha$ competent cells (Invitrogen, Life Technologies, Carlsbad, CA). Plasmid DNA was purified with the QIAprep Spin Miniprep kit (Qiagen, Valencia, Ca) and digested with EcoR I to confirm the presence of an insert. Sequencing was performed using SP6 or M13 forward primers at the Michigan State University Research Technology Support Facility (MSU RTSF). Putative identification of the amplicons was determined using the basic local alignment search tool (BLASTn) software, with the non-redundant and EST databases of GenBank and The Institute for Genomic Research (TIGR) database. Correct gene name and abbreviation was corroborated using the Gene Cards ${ }^{\circledast}$ database http://www.genecards.org.

\section{Oligonucleotide microarray analysis}

Oligonucleotide microarrays used for this study consisted of 13,297 70-mer oligos (Pig Array-Ready Oligo Set v. 1.0 and Pig Oligo Extension Set v. 1.0, Qiagen, Inc., Valencia, CA) each spotted once on a single slide. Slides were printed at the MSU RTSF. Oligonucleotides spotted in multiple locations for use as potential controls included 76 Arabidopsis thaliana gene spots, 17 beta tubulin spots, 17 glyceraldehyde-3-phosphate dehydrogenase spots, 85 heat shock protein gene spots, 69 ribosomal protein gene spots, 112 randomly generated negative control spots and 470 blanks. This microarray has been validated for use in pig transcriptional profiling studies by Zhao et al. [66]. The microarray was screened with the $Z_{150}$ and $Z_{2000}$ samples. $\mathrm{Zn}_{150}$ samples were randomly paired with $\mathrm{Zn}_{2000}$ samples using four microarray slides. Two samples from each treatment were labeled with $\mathrm{Cy} 3$ and the other two were labeled with Cy5.

For each sample, $8 \mu \mathrm{g}$ of total RNA was reverse transcribed with an oligo $(\mathrm{dT})_{18}$ primer using the Superscript ${ }^{\mathrm{TM}}$ Indirect cDNA Labeling System (Invitrogen, Carlsbad, CA) according to the manufacturer's instructions. After firststrand synthesis and purification, the cDNAs incorporated amino-modified dUTPs and were labeled with $N$-hydroxysuccinate (NHS) ester Cy3 or Cy5 dyes (GE Healthcare, Piscataway, NJ). The labeled cDNAs were purified, combined and concentrated to $10 \mu \mathrm{l}$ using a microcon spin column (Millipore, Bedford, MA). The concentrated probe was combined with $100 \mu$ l of Slide Hyb\#3 solution (Ambion, Inc. Austin, TX) and denatured at $70^{\circ} \mathrm{C}$ for 5 min. Microarray hybridizations took place in sealed hybridization chambers in a GeneTAC ${ }^{\mathrm{TM}}$ Hybridization Station (Genomic Solutions) for 18 hours using stepdown temperatures ranging from $65^{\circ} \mathrm{C}$ to $42^{\circ} \mathrm{C}$. Following hybridization, the slides were washed twice with medium stringency buffer and once with high stringency buffer (Genomic Solutions). The slides were rinsed in $2 \times$ SSC and deionized water and were dried using centrifugation at $1000 \times \mathrm{g}$ for $2 \mathrm{~min}$. Fluorescent images were detected on a GenePix 4000B scanner (Molecular Devices, Sunnyvale, CA). Fluorescence intensity data were collected using GenePix software (Molecular Devices) after spot alignment. The dataset was submitted to the National Center for Biotechnology Information's Gene Expression Omnibus database [GEO:GSE11972]. Total intensity values for each dye channel were stored as comma-separated values data files and exported into Microsoft Excel spreadsheets for subsequent analysis. The fluorescence intensity data was background corrected and analyzed using the limma software [67]. Specifically, the "normexp" function advocated by Smyth [67] was used for background subtraction followed by print-tip specific loess normalization for dye intensity bias for each array. The Cy5:Cy5 log2 ratios were further scale normalized between arrays. A simple linear model fitting these ratios as a function of an overall intercept(dye) and treatment effects was fitted for each gene using the "eBayes" option in limma. Statistical significance was based on the estimated false discovery rates (FDR) as also provided by limma.

\section{Independent confirmation by relative real time $R T-P C R$}

Transcript abundance of ORM1 was examined for liver samples from Exp.1 ( $\mathrm{n}=4$ fed $\mathrm{Zn}_{150}$ and $\mathrm{n}=3$ fed $\left.\mathrm{Zn}_{2000}\right)$. Transcript abundances of 7 genes (ACY1, GLO1, PRDX4, CPB2, ORM1, GSTM4 and HSP70.2) were evaluated for 23 liver samples from Exp. 2. The RNA sample for 1 pig fed $\mathrm{Zn}_{150} \mathrm{P}$ (Exp.2) was of poor quality, and was not included in the analyses. Glyceraldehyde-3-phosphate dehydrogenase (GAPDH) or $18 S$ ribosomal RNA (18S) were used as normalizing genes. Relative real time RT-PCR primers (Table 3) were designed using Primer Express v. 2.0 (Applied Biosystems, Foster City, CA), and the assays were performed on an ABI Prism 7000 Sequence Detection System (Applied Biosystems, Foster City, CA) in the Michigan State University Center for Animal Functional Genomics. First strand cDNA synthesis was performed with an oligo $(\mathrm{dT})_{14}$ primer using SuperScript II RNase H (Invitrogen Life Technologies) following the manufacturer's protocol. The cDNA was purified with QuickClean resin (Clontech) followed by precipitation with sodium acetate and ethanol. Purified cDNAs were suspended in DNase/RNase-free sterile water, and quantified using a spectrophotometer. The cDNA samples were diluted to a final concentration of $10 \mathrm{ng} / \mu \mathrm{l}$ and stored at $-20^{\circ} \mathrm{C}$ until use. The real time 
Table 3: Real time RT-PCR primers used for DDRT-PCR and microarray confirmation ${ }^{\mathrm{a}}$.

\begin{tabular}{lll}
\hline Gene & Direction & Primer sequence \\
\hline CPB2 & Forward & 5'-TGG CAT GTC ATC AGA AAT GGT T-3' \\
CPB2 & Reverse & 5'-CTT GCT GGA ATC AGT AAA TTT CAC TCT-3' \\
GSTM4 & Forward & 5'-CCA TCC TGC GCT ACA TTG C-3' \\
GSTM4 & Reverse & 5'-CTC CAA AAC ATC CAC TCG AAT CT-3' \\
HSP70.2 & Forward & 5'-GTT CGG TTT CCG GCT TCA-3' \\
HSP70.2 & Reverse & 5'-CTC TCT CCG CAA ACA GCC TCT A-3' \\
ORMI & Forward & 5'-TTG AGT GCA CGG GAA TCC A-3' \\
ORMI & Reverse & 5'-CCA GCG GCC CAC ACA-3' \\
PRDX4 & Forward & 5'-ATG ACC TCC CTG TGG GTA GAT CT-3' \\
PRDX4 & Reverse & 5'-ACA GAC TTC TCC ATG TTT GTC AGT GT-3' \\
GAPDH & Forward & 5'-TGG AAA GGC CAT CAC CAT CT-3' \\
GAPDH & Reverse & 5'-CCA GCA TCG CCC CAT TT-3' \\
I8Sb & Forward & 5'-CGG CTA CCA CAT CCA AGG AA-3' \\
I8S & Reverse & 5'-GCT GGA ATT ACC GCG GCT-3' \\
\hline
\end{tabular}

aPrimers were designed using Primer Express v. 2.0 (1995-2000).

b $18 \mathrm{~S}$ primers were graciously provided by Dr. Susan Ewart of the Molecular Respiratory and Equine Genetics Laboratory at Michigan State University.

RT-PCR reactions included $50 \mathrm{ng}$ of cDNA, $300 \mu \mathrm{M}$ primer and $1 \times$ SYBR Green Master Mix (Applied Biosystems, Foster City, CA).

Relative quantification was determined using duplicate cDNA samples from each animal. PCR amplification efficiency plots were generated using serially diluted cDNA (4 dilutions) to confirm the use of GAPDH or $18 S$ as normalizing genes for each primer pair. Results were recorded relative to a common liver cDNA sample from a pig fed $\mathrm{Zn}_{150}$ after normalizing for GAPDH or $18 S$. Relative gene expression changes were then computed using the $2^{-\Delta \Delta \mathrm{Ct}}$ method [68].

\section{Independent confirmation by northern blot hybridization} When PCR amplification plots did not reveal equal amplification efficiency for GAPDH with the target gene, confirmation of DDRT-PCR results for some genes was done by northern blot analysis using the cDNA clones obtained by DDRT-PCR, labeled as described previously [11] with an $18 S$ rRNA for normalization.

\section{Statistical analysis}

The data were analyzed using analysis of variance based on the MIXED procedure of SAS [69]. If the main effects (Zn or phytase) or their interaction were not statistically significant, the datasets were merged. For the relative real time RT-PCR analyses, the model included pig nested within the treatment interaction with the plate as random effect. Satterthwaite's approximation was used to determine the error $\mathrm{df}$ for test [70]. A base 2 logarithmic transformation $\left(\log _{2}\right)$ of the target and normalization gene Cts was made to account for the exponential amplification of cDNA prior to analyzing Ct values with the MIXED proce- dure of SAS. The transformed target Cts, and GAPDH or $18 \mathrm{~S}$ Cts modeled as covariates, were used in a regressionbased normalization of $\mathrm{Cts}$ in accordance with recommendations by Poehlman [71]. These values were compared to the results calculated by using the $2^{-\Delta \Delta \mathrm{Ct}}$ method [68], and data is presented as fold changes. For northern blot analyses, the blot by treatment interaction was used in the model with pig as a random effect. The $18 \mathrm{~S}$ rRNA values were modeled as covariates for a regression-based normalization of the genes' relative mRNA abundance. Differences were considered to be significant when $P<$ 0.05 .

\section{Authors' contributions}

MMM performed the animal study, prepared and analyzed the diets, helped in tissue collection, carried out part of experiment 2 DDRT-PCR reactions, performed most of the bioinformatics and statistical analyses, performed part of the confirmation assays and prepared the manuscript. GMH obtained the animals for this study, helped in obtaining the tissues, designed and coordinated the nutrition study as the PI, and helped draft the manuscript. NER helped in tissue collection, performed experiment 1 DDRT-PCR analysis, conducted part of the real time RTPCR confirmation, and helped draft the manuscript. VDR performed part of the real time RT-PCR confirmation and conducted some of the real time RT-PCR statistical analyses. RJT performed statistical analysis of the microarray data and assisted with analysis of real time RT-PCR data. JEL prepared and analyzed the nutritional composition of the diets and helped with tissue collection. CJW carried out part of experiment 2 DDRT-PCR reactions. AMR carried out the microarray hybridizations. CWE helped in obtaining the tissues, designed and coordinated the 
DDRT-PCR and microarray studies as the PI, and prepared the manuscript. All authors have read and approved the final manuscript.

\section{Additional material}

\section{Additional file 1}

Pharmacological zinc supplementation-related changes in $m R N A$ abundance in pig liver determined by oligonucleotide microarray analysis (FDR $<0.054)$. The data provided are results of oligonucleotide microarray analysis comparing pigs fed an adequate $\mathrm{Zn}$ diet $(150 \mathrm{mg} \mathrm{Zn} /$ $\mathrm{kg})$ to pigs fed a pharmacological $\mathrm{Zn}$ diet $(2,000 \mathrm{mg} \mathrm{Zn} / \mathrm{kg})$.

Click here for file

[http://www.biomedcentral.com/content/supplementary/14712164-9-421-S1.xls]

\section{Acknowledgements}

The authors express their appreciation to Max Rothschild, U.S. Swine Genome Coordinator, for distribution of the DDRT-PCR oligonucleotide primers. The technical assistance of the staff at the Michigan State University Center for Animal Functional Genomics, Kim Hargrave and Megan Closs is gratefully acknowledged. This work was supported in part by an Animal Health Formula Funds Grant from the Michigan Agricultural Experiment Station, and The Graduate School - Competitive Doctoral Enrichment Fellowship, Michigan State University, East Lansing, MI.

\section{References}

I. Junghans P, Kaehne T, Beyer M, Metges CC, Schwerin M: Dietary protein-related changes in hepatic transcription correspond to modifications in hepatic protein expression in growing pigs. J Nutr 2004, I34:43-47.

2. Hesketh JE, Vasconcelos MH, Bermano G: Regulatory signals in messenger RNA: determinants of nutrient-gene interaction and metabolic compartmentation. Br J Nutr 1998, 80:307-321.

3. Falchuk KH: The molecular basis for the role of zinc in developmental biology. Mol Cell Biochem 1998, 188:4I-48.

4. Andreini C, Banci L, Bertini I, Rosato A: Counting the zinc-proteins encoded in the human genome. J Proteome Res 2006, 5:196-20I.

5. Kagi RH]: Evolution, structure and chemical activity of class I metallothioneins: overview. In Metallothioneins III Edited by: Suzuki KT, Imura N, Kimura M. Switzerland: Birkhauser Verlag Basel; 1993:29-56.

6. Richards MP, Cousins RJ: Mammalian zinc homeostasis requirement for RNA and metallothionein synthesis. Biochem Biophys Res Comm 1975, 64:1215-1223.

7. Prassad A: Zinc in Human Health: Effect of Zinc on Immune Cells. Mol Med 2008, 14:353-357.

8. Harland BF, Morris ER: Phytate: A good or a bad food component. Nutr Res 1995, 15:733-754.

9. Davies NT, Nightingale R: The effects of phytate on intestinal absorption and secretion of zinc, and whole-body retention of zinc, copper, iron and manganese in rats. Br J Nutr 1975, 34:243-258.

10. Lei X, Ku PK, Miller EW, Ullrey DE, Yokoyama M: Supplemental microbial phytase improves bioavailability of dietary zinc to weanling pigs. J Nutr 1993, I 23: I I I 7-I I 23.

II. Martínez MM, Hill GM, Link JE, Raney NE, Tempelman RJ, Ernst CW: Pharmacological zinc and phytase supplementation enhance metallothionein mRNA abundance and protein concentration in newly weaned pigs. J Nutr 2004, 134:538-544.

12. Adeola $O$, Lawrence B, Sutton A, Cline T: Phytase-induced changes in mineral utilization in zinc-supplemented diets for pigs. J Anim Sci 1995, 73:3384-3391.

13. Cromwell GL, Coffey MT, Monegue HJ, Randolph JH: Efficacy of low-activity, microbial phytase in improving the bioavailabil- ity of phosphorus in corn-soybean meal diets for pigs. J Anim Sci 1995, 73:449-456.

14. Sandberg AS, Hulthen LR, Turk M: Dietary Aspergillus niger phytase increases iron absorption in humans. J Nutr 1996, I 26:476-480.

15. Bhutta ZA, Bird SM, Black RE, Brown KH, Gardner JM, Hidayat A: Therapeutic effects of oral zinc in acute and persistent diarrhea in children in developing countries: pooled analysis of randomized controlled trials. Am J Clin Nutr 2000, 72:1516-1522.

16. Rosado JL, López P, Muñoz E, Martinez H, Allen LH: Zinc supplementation reduced morbidity, but neither zinc nor iron supplementation affected growth or body composition of Mexican preschoolers. Am J Clin Nutr 1997, 65:13-19.

17. Boulay M, Scott ME, Conly SL, Stevenson MM, Koski KG: Dietary protein and zinc restrictions independently modify a Heligmosomoides polygyrus (Nematoda) infection in mice. Parasitology 1998, I I 6(Pt 5):449-62.

18. Hill GM, Cromwell GL, Crenshaw TD, Dove CR, Ewan RC, Knabe DA, Lewis AJ, Libal GW, Mahan DC, Shurson GC, Southern LL, Veum TL: Growth promotion effects and plasma changes from feeding high dietary concentrations of zinc and copper to weanling pigs (regional study). J Anim Sci 2000, 78:1010-1016.

19. Carlson MS, Hill GM, Link JE: Early- and traditionally weaned nursery pigs benefit from phase-feeding pharmacological concentrations of zinc oxide: effect on metallothionein and mineral concentrations. J Anim Sci 1999, 77: I I99-I 207.

20. Jin DY, Chae HZ, Rhee SG, Jeang KT: Regulatory role for a novel human thioredoxin peroxidase in Nf- $K \mathbf{B}$ activation. J Biol Chem 1997, 272:30952-3096|.

21. Ranganathan S, Ciaccio PJ, Walsh ES, Tew KD: Genomic sequence of human glyoxalase-l: analysis of promoter activity and its regulation. Gene 1999, 240:149-155.

22. Mitta M, Ohnogi H, Yamamoto A, Kato I, Sakiyama F, Tsunasawa S: The primary structure of porcine aminoacylase I deduced from cDNA sequence. J Biochem 1992, I I 2:737-742.

23. Liang $P$, Pardee $A B$ : Differential display of eukaryotic messenger RNA by means of the polymerase chain reaction. Science |992, 257:967-97|.

24. Cousins RJ, Blanchard RK, Moore JB, Cui L, Green CL, Liuzzi JP, Cao J, Bobo JA: Regulation of zinc metabolism and genomic outcomes. J Nutr 2003, I33:152 IS-1526S.

25. Stein J, Liang P: Differential display technology: a general guide. Cell Mol Life Sci 2002, 59:1235-I240.

26. Gallagher BM, Phelan SA: Investigating transcriptional regulation of PRDX6 in mouse liver cells. Free Radic Biol Med 2007, 42: $1270-1277$.

27. Sakurai A, Hara S, Okano N, Kondo Y, Inoue J, Imura N: Regulatory role of metallothionein in NF-[kappa]B activation. FEBS Letters 1999, 455:55-58.

28. Zhou Z, Wang L, Song Z, Saari JT, McClain CJ, Kang YJ: Abrogation of nuclear factor-kappaB activation is involved in zinc inhibition of lipopolysaccharide-induced tumor necrosis factoralpha production and liver injury. Am J Pathol 2004, 164:1547-1556

29. Kim CH, Kim JH, Lee J, Ahn YS: Zinc-induced NF- $\mathrm{K}$ B inhibition can be modulated by changes in the intracellular metallothionein level. Toxicol Appl Pharmacol 2003, 190:189-196.

30. Uzzo RG, Crispen PL, Golovine K, Makhov P, Horwitz EM, Kolenko VM: Diverse effects of zinc on NF- $K B$ and AP-I transcription factors: implications for prostate cancer progression. Carcinogenesis 2006, 27: 1980-1990.

31. Roselli M, Finamore A, Garaguso I, Britti MS, Mengheri E: Zinc oxide protects cultured enterocytes from the damage induced by Escherichia coli. J Nutr 2003, 133:4077-4082.

32. Creighton DJ, Hamilton DS: Brief history of glyoxalase I and what we have learned about metal ion-dependent, enzyme catalyzed isomerizations. Arch Biochem Biophys 2001, 387: I-10.

33. Creighton DJ, Migliorini M, Pourmotabbed T, Guha MK: Optimization of efficiency in the glyoxalase pathway. Biochemistry 1988, 27(19):7376-84.

34. Brambilla G, Sciaba L, Faggin P, Finollo R, Bassi AM, Ferro M, Marinari UM: Methylglyoxal-induced DNA-protein cross-links and cytotoxicity in Chinese hamster ovary cells. Carcinogenesis 1985, 6:683-686. 
35. Stuart GW, Searle PF, Cen HY, Brinster RL, Palmiter RD: A I 2-basepair DNA motif that is repeated several times in metallothionein gene promoters confers metal regulation to a heterologous gene. Proc Natl Acad Sci USA 1984, 81:73 I8-7322.

36. Radtke F, Heuchel R, Georgiev O, Hergersberg M, Gariglio M, Dembic Z, Schaffner W: Cloned transcription factor MTF-I activates the mouse metallothionein I promoter. EMBO J 1993 , I 2: | $355-1362$

37. Ho $E$, Ames $B N$ : Low intracellular zinc induces oxidative DNA damage, disrupts p53, NFkappaB and API binding and affects DNA repair in a rat glioma cell line. Proc Natl Acad Sci USA 2002, 99:16770-16775

38. Denson J, Xi Z, Wu Y, Yang W, Neale G, Zhang J: Screening for inter-individual splicing differences in human GSTM4 and the discovery of a single nucleotide substitution related to the tandem skipping of two exons. Gene 2006, 379:। 148-155.

39. tom Dieck H, Döring F, Roth HP, Daniel $\mathrm{H}$ : Changes in rat hepatic gene expression in response to zinc deficiency as assessed by DNA arrays. J Nutr 2003, 133:1004-1010.

40. Wong KL, Klaassen CD: Relationship between liver and kidney levels of glutathione and metallothionein in rats. Toxicology 1981, 19:39-47.

4l. Haïdara K, Moffatt P, Denizeau F: Metallothionein induction attenuates the effects of glutathione depletors in rat hepatocytes. Toxicol Sci 1999, 49:297-305.

42. Har-El R, Chevion M: Zinc (II) protects against meta-mediated free radical induced damage: studies on single and doublestrand DNA breakage. Free Radic Res Commun 1990, I2|3:509-5I5.

43. Imai J, Yashiroda H, Maruya M, Yahara I, Tanaka K: Proteasomes and molecular chaperones: cellular machinery responsible for folding and destruction of unfolded proteins. Cell Cycle 2003, 2:585-590.

44. Bernardini C, Zannoni A, Turba ME, Fantinati P, Tamanini C, Bacci ML, Forni M: Heat shock protein 70 , heat shock protein 32 , and vascular endothelial growth factor production and their effects on lipopolysaccharide-induced apoptosis in porcine aortic endothelial cells. Cell Stress Chaperones 2005, 10:340-348.

45. Hatayama T, Hayakawa M: Differential temperature dependency of chemical stressors in HSFI-mediated stress response in mammalian cells. Biochem Biophys Res Commun 1999, 265:763-769.

46. Higashi T, Takechi H, Uemura Y, Kikuchi H, Nagata K: Differential induction of mRNA species encoding several classes of stress proteins following focal cerebral ischemia in rats. Brain Res 1994, 650:239-248.

47. Söti C, Csermely P: Aging and molecular chaperones. Exp Gerontol 2003, 38( I 0): 1037-40.

48. Lindner H, Hopfner S, Tafler-Naumann M, Miko M, Konrad L, Rohm $\mathrm{KH}$ : The distribution of aminoacylase I among mammalian species and localization of the enzyme in porcine kidney. Biochimie 2000, 82:129-137.

49. Giardina T, Biagini A, Dalle Ore F, Ferre E, Reynier M, Puigserver A: The hog intestinal mucosa acylase I: Subcellular localization, isolation, kinetic studies and biological function. Biochimie 1997, 79:265-273.

50. Loffler HG, Rohm KH, Schneider F: Studies on metal ion dependence, kinetics and SH (S-S) groups of acylaminoacid aminohydrolase. In Zinc Enzymes Edited by: Bertini I, Luchinat C, Maret W, Zeppezauer M. Boston: Birkhauser; 1986:28I-288.

51. Heese D, Berger S, Rohm KH: Nuclear magnetic relaxation studies of the role of the metal ion in $\mathrm{Mn}+2$-substituted aminoacylase I. Eur J Biochem 1990, I 88:175-180.

52. Dente L: Human alpha-I-acid glycoprotein genes. Prog Clin Biol Res 1989, 300:85-98.

53. Tan AK, Eaton DL: Activation and characterization of procarboxypeptidase B from human plasma. Biochemistry 1995 34:58| I-58|6.

54. Lampreave $F$, Pineiro A: The major serum protein of fetal and newborn pigs: biochemical properties and identification as a fetal form of alpha I-acid glycoprotein. Int J Biochem 1984, 16:47-53.

55. Son DS, Shimoda M, Kokve E: Implication of altered levels of plasma alpha (I)-acid glycoprotein and its derived sialic acid on plasma protein binding of trimethoprim in pigs in physiological and pathological states. Vet $Q$ 1996, 18:10-13.
56. Stone RT, Maurer RA: Cloning and developmental regulation of alpha I acid glycoprotein in swine. Dev Genet 1987, 8:295-304.

57. Mackiewicz A, Dewey MJ, Berger FG, Baumann H: Acute phase mediated change in glycosylation of rat $\alpha \mathrm{I}$-acid glycoprotein in transgenic mice. Glycobiology 1991, I:265-269.

58. Cooper R, Eckley DM, Papaconstantinou J: Nucleotide sequence of the mouse alpha I-acid glycoprotein gene I. Biochemistry 1987, 26:5244-5250.

59. Yiangou M, Ge X, Carter K, Papaconstantinou J: Induction of several acute-phase protein genes by heavy metals: a new class of metal-responsive genes. Biochemistry 1991, 30:3798-3806.

60. Hendriks D, Scharpé S, van Sande M, Lommaert MP: Characterization of a carboxypeptidase in human serum distinct from carboxypeptidase N. J Clin Chem Clin Biochem 1989, 27:277-285.

6I. Bouma BN, Marx PF, Mosnier LO, Meijers JCM: Thrombin-Activatable Fibrinolysis Inhibitor (TAFI, Plasma Procarboxypeptidase B, Procarboxypeptidase R, Procarboxypeptidase U). Thromb Res 200I, 10 I:329-354.

62. Eaton DL, Malloy BE, Tsai SP, Henzel W, Drayna D: Isolation, molecular cloning, and partial characterization of a novel carboxypeptidase B from human plasma. J Biol Chem I991, 266:21833-21838.

63. Schatteman KA, Goossens FJ, Scharpe SS, Hendriks D: Activation of plasma carboxypeptidase $U$ in different mammalian species points to a conserved pathway of inhibition of fibrinolysis. Thromb Haemost 1999, 82:1718-1721.

64. Wang W, Boffa PB, Bajzar L, Walker JB, Nesheim ME: A study of the mechanism of inhibition of fibrinolysis by activated thrombin-activatable fibrinolysis inhibitor. J Biol Chem 1998, 273:27|76-27|8I.

65. Wesolowski SR, Raney NE, Ernst CW: Developmental changes in the fetal pig transcriptome. Physiol Genomics 2004, I6:268-274.

66. Zhao SH, Recknor J, Lunney JK, Nettleton D, Kuhar D, Orley S, Tuggle CK: Validation of a first-generation long-oligonucleotide microarray for transcriptional profiling in the pig. Genomics 2005, 86:618-625.

67. Smyth GK: Limma: linear models for microarray data. In Bioinformatics and Computational Biology Solutions Using R and Bioconductor Edited by: Gentleman R, Carey V, Dudoit S, Irizarry R, Huber W. New York: Springer; 2005:397-420.

68. Livak KJ, Schmittgen TD: Analysis of relative gene expression data using real-time quantitative PCR and the 2(-Delta Delta C(T)) method. Methods 200I, 25:402-408.

69. SAS Systems: The SAS System for Windows, version 9.1.3. SAS Institute, Inc., Cary, NC; 2007.

70. Satterthwaite FE: An approximate distribution of estimates of variance components. Biometrics Bull 1946, 2: I I0-I I4.

71. Poehlman ET: Reduced metabolic rate after caloric restriction-can we agree on how to normalize the data? J Clin Endocrinol Metab 2003, 88: 14-15.

Publish with Biomed Central and every scientist can read your work free of charge

"BioMed Central will be the most significant development for disseminating the results of biomedical research in our lifetime. "

Sir Paul Nurse, Cancer Research UK

Your research papers will be:

- available free of charge to the entire biomedical community

- peer reviewed and published immediately upon acceptance

- cited in PubMed and archived on PubMed Centra

- yours - you keep the copyright
BioMedcentral 